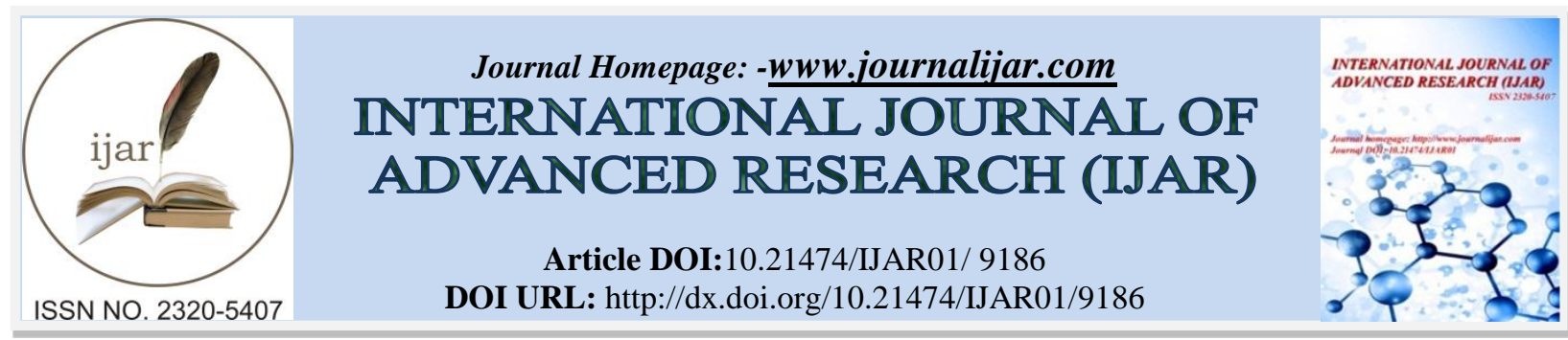

RESEARCH ARTICLE

\title{
STUDY OF ETIOLOGICAL AND CLINICAL PROFILE OF PLEURAL EFFUSION IN A TERITARY CARE HOSPITAL -A RETROSPECTIVE ANALYSIS.
}

1. Registrar medicine, post graduate department of medicine, gmc jammu.

2. Lecturer medicine, post graduate department of medicine, gmc jammu.

\section{Manuscript Info}

Manuscript History

Received: 26 March 2019

Final Accepted: 28 April 2019

Published: May 2019

\begin{abstract}
Pleural effusion can cause significant symptoms and diminished quality of life, but more importantly, is associated with increased risk of respiratory failure and mortality. This hospital based study was carried out on 546 patients to find the etiological profile and clinical presentation of patients with pleural effusion in Jammu region of J\&K. Results of this study revealed that Tubercular effusion, par pneumonic effusion, malignant effusion, Congestive cardiac failure, Liver disease, Renal disease are major important disease factors with various presenting feature of patients with pleural effusion, mainly shortness of breath, fever, cough, chest pain, oedema, haemoptysis and weight loss. This study would help in early diagnosis and possible intervention and prompt treatment of patients with pleural effusion.
\end{abstract}

Copy Right, IJAR, 2019,. All rights reserved.

\section{Introduction:-}

Pleural effusion is an abnormal collection of fluid in the pleural space. The etiological spectrum of pleural effusion depends on the geographical region and the local incidence of different diseases that cause pleural effusions. In the developed countries the common causes of pleural effusion in adult are cardiac failure, malignancy and pneumonia(1,2).Whereas in developing countries tuberculosis and par pneumonic effusions are more prevalent. $(3,4$ )The pleural space normally contains $0.1-0.2 \mathrm{ml} / \mathrm{kg}$ body weight of fluid, filtered from systemic capillaries down a small pressure gradient. Fluid may accumulate in the pleural space by a number of mechanisms: increased pulmonary capillary pressure, decreased (more negative) intrapleural pressure (e.g. Atelectasis), decreased plasma oncotic pressure (e.g. hypoalbuminaemia), increased pleural membrane permeability and obstructed lymphatic flow (e.g. pleural malignancy or infection).(5,6) When local factors are altered, the fluid is rich in protein and lactate dehydrogenase $(\mathrm{LDH})$ and is called an exudate.

A systemic approach to the investigations is needed because of the extensive differential diagnosis. Pleural effusions can be transudative or exudative. $(7,8)$ In cases with transudative pleural effusion the diagnosis is usually made without much difficulties but exudative pleural effusion requires careful differential diagnosis that includes par pneumonic effusion, tuberculosis, and metastatic cancers which are found to be the cases in large number of patients. $(9,10)$

Criteria known as Light's criteria define the exudative and transudative effusion. An exudative effusion will have a ratio of pleural fluid protein to serum protein greater than 0.5 , a ratio of pleural fluid lactate dehydrogenase to serum

Corresponding Author:-Dr. Deepak Bharti.

Address:-Registrar medicine, post graduate department of medicine, gmc jammu. 
lactate dehydrogenase greater than 0.6 or a pleural fluid lactate dehydrogenase greater than two thirds the upper limit of normal for serum lactate dehydrogenase. The mortality of empyema is as high as $15 \%$ and up to $40 \%$ of these patients require surgery because medical treatment has failed.(11,12,13) Tuberculosis pleurisy may occur during primary infection, when it tends to affect younger individuals in areas with a high prevalence of tuberculosis, or it may be recognized as a manifestation of disease reactivation, particularly affecting older patients.(14-16) Although pleural effusion is a common clinical problem confronting physicians in India, there has never been a systematic study of the diseases causing pleural effusion in this country especially in Jammu region of Jammu and Kashmir. This prompted us to conduct this study to define the etiology of pleural effusions in this region of Jammu, and to evaluate the roles of pleural fluid analysis in the diagnosis of malignant and tuberculous effusions.

\section{Material \& methods:-}

The observational hospital based study was carried out in the department of medicine Govt. Medical College and Hospital, Jammu.This is a retrospective study where data from all the cases diagnosed with pleural effusion in the medicine department of GMC Jammu from January 2018 to December 2018 were included. Data was taken from medical record section.

Patient's demographics were enlisted alphabetically to avoid inclusion of same patient more than once. Any patients with confusion were deleted from the study. This study involved all adult patients ( $>18$ years) with pleural effusions who were admitted to GMC Jammu. Patients underwent thoracentesis after Ultrasonography under aseptic conditions, a 16gauge needle was used, and 50-100 mL samples of pleural fluid were collected and immediately sent to the biochemical, cytological and microbiological laboratories for analysis. At the same time, blood samples were taken for simultaneous pleural fluid and blood determination of the levels of total protein, albumin, lactate dehydrogenase and glucose.

Observation:-

Observations are represented below in tables

\section{Results:-}

Table 1 shows, Out of 546 patients of Pleural effusion studied, majority of patients were more than 56 years (52.4\%) and were males $75.1 \%$ (Table-2).

Commonest symptom of pleural effusion is shortness of breath in 386 patients $(70.7 \%)$, followed by cough in 56.8 $\%$ patients (Table-3).

Majority of patients presented with right side pleural effusion, seen in 316 patients (57.9\%).(Table 4)

$68.9 \%$ patients presented with exudates effusion (68.9\%).(Table 5)

Commonest cause of pleural effusion is tuberculosis in 120 patients (22\%), and other causes are depicted below (Table-6).

Most common complication was pneumothorax (2.4\%), followed by syncope (1.1\%), and hemothorax (1.5\%).(Table 7)

\section{Discussion:-}

Out of 546 patients of pleural effusion studied, majority of patients were more than 56 years (52.4\%) and were males $75.1 \%$ (Table-1 \& 2). this finding is consistent with poor and developing countries studies(3-4 )but differ from some western studies(1-2) due to low prevalence of infectious disease in their population. Our study concludes that the tubercular effusion is the commonest cause of pleural effusion followed by malignancy ,par pneumonic effusion and congestive heart failure .(Table-3).

But in developed countries as shown in study by Storey and co-workers (9) reported that malignancy accounted for nearly $50 \%$ of patients with pleural effusion. Tubercular effusion is the common cause of exudative pleural effusion in many areas of the world(17-18) which is consistent with our study which shows that 120 patients were having tubercular effusion out of 546 patients. 
Tubercular effusion and par pneumonic effusion predominantly in younger patients but pleural effusion due to malignancy and congestive cardiac failure is common in old patients. Shortness of breath, fever and cough are the commonest mode of clinical presentation. This study also shows that in par pneumonic effusion mean total neutrophil is $72 \%$ which shows that par pneumonic effusion is an acute process affecting pleura whereas predominance of mononuclear cells indicates a chronic process. A preponderance of small lymphocytes indicates that the patient most likely has cancer or tuberculous pleuritis.(19-20) This study is just the retrospective crosssectional study, with small sample size, the findings should be interpreted with caution. However our study collaborates well with the other study and shows the various mode of clinical presentation, importance of sputum profile and pleural fluid analysis in patient presenting with pleural effusion. Further study would be required to determine the complete clinical profile patient presenting with pleural effusion in this region.

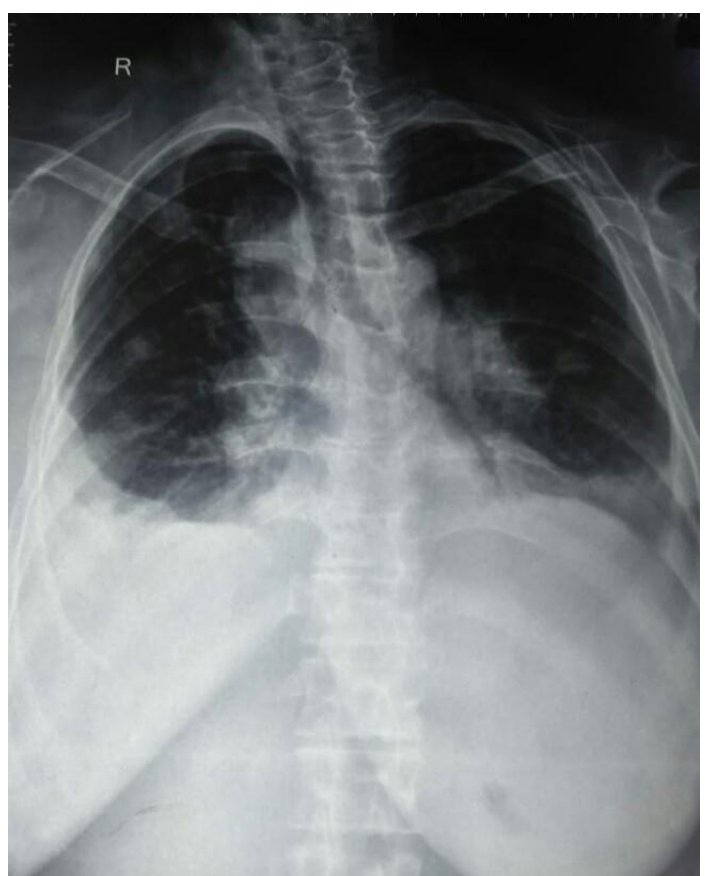

Picture 1:-X Ray Chest PA view showing Bilateral pleural Effusion (Rt $>\mathrm{Lt}$ )

Table 1:-Age Distribution

\begin{tabular}{|l|l|l|}
\hline AGE (IN YRS) & NUMBER OF PATIENTS (N) & PERCENTAGE (\%) \\
\hline $18-25$ & 36 & 6.6 \\
\hline $26-35$ & 52 & 9.5 \\
\hline $36-45$ & 66 & 12.1 \\
\hline $46-55$ & 106 & 19.4 \\
\hline $56-65$ & 151 & 27.7 \\
\hline$>65$ & 135 & 24.7 \\
\hline TOTAL & 546 & 100 \\
\hline
\end{tabular}

Table 2:-Sex Distribution

\begin{tabular}{|l|l|l|}
\hline SEX & NUMBER OF PATIENTS(N) & PERCENTAGE (\%) \\
\hline MALE & 410 & 75.1 \\
\hline FEMALE & 136 & 24.9 \\
\hline TOTAL & 546 & 100 \\
\hline
\end{tabular}

Table 3:-Symptomology Of Patients

\begin{tabular}{|l|l|l|}
\hline SYMPTOMS & NUMBER OF PATIENTS (N) & PERCENTAGE (\%) \\
\hline SHORTNESS OF BREATH & 386 & 70.7 \\
\hline COUGH & 310 & 56.8 \\
\hline
\end{tabular}




\begin{tabular}{|l|l|l|}
\hline FEVER & 226 & 41.4 \\
\hline CHEST PAIN & 164 & 30 \\
\hline EDEMA & 78 & 14.3 \\
\hline HEMOPTYSIS & 74 & 13.6 \\
\hline WEIGHT LOSS & 70 & 12.8 \\
\hline ANOREXIA & 66 & 12.1 \\
\hline
\end{tabular}

Table 4:-Distributions Based On Laterality Of Involvement

\begin{tabular}{|l|l|l|}
\hline ATTRIBUTE & NUMBER OF PATIENTS (N) & PERCENTAGE (\%) \\
\hline RIGHT SIDE PLEURAL EFFUSION & $\mathbf{3 1 6}$ & $\mathbf{5 7 . 9}$ \\
\hline LEFT SIDE PLEURAL EFFUSION & $\mathbf{9 6}$ & $\mathbf{1 7 . 6}$ \\
\hline BILATERAL PLEURAL EFFUSION & $\mathbf{1 3 4}$ & $\mathbf{2 4 . 5}$ \\
\hline TOTAL & $\mathbf{5 4 6}$ & $\mathbf{1 0 0}$ \\
\hline
\end{tabular}

Table 5:-Pleural Fluid Analyses.

\begin{tabular}{|l|l|l|}
\hline ATTRIBUTE & NUMBER OF PATIENTS(N) & PERCENTAGE (\%) \\
\hline EXUDATE & 376 & 68.9 \\
\hline TRANSUDATE & 170 & 31.1 \\
\hline TOTAL & $\mathbf{5 4 6}$ & 100 \\
\hline
\end{tabular}

Table 6:-Etiological Distributions Of Patients Based On Pleural Fluid Cytology And Biochemical, History And Clinical Examination Of Patients.

\begin{tabular}{|l|l|l|}
\hline ETIOLOGY & NUMBER OF PATIENTS (N) & PERCENTAGE (\%) \\
\hline TUBERCULOSIS & 120 & 22 \\
\hline MALIGNANCY & 77 & 14.1 \\
\hline SYNPNEUMONIC EFFUSION & 66 & 12.1 \\
\hline LIVER CIRRHOSIS CARDIAC & 49 & 9 \\
\hline $\begin{array}{l}\text { CONGESTIVE } \\
\text { FAILURE }\end{array}$ & 15.4 \\
\hline PANCREATITIS & 65 & 11.9 \\
\hline RENAL DISEASE (AKI/CKD) & 49 & 9 \\
\hline POST-OPERATIVE & 14 & 2.5 \\
\hline IDIOPATHIC & 22 & 4 \\
\hline
\end{tabular}

Table 7:-Complications From Thoracocentesis

\begin{tabular}{|l|l|l|}
\hline COMPLICATIONS & NUMBER OF PATIENTS $(\mathbf{N})$ & PERCENTAGE $(\%)$ \\
\hline PNEUMOTHORAX & 13 & 2.4 \\
\hline SYNCOPE & 6 & 1.1 \\
\hline HEMOTHORAX & 8 & 1.5 \\
\hline
\end{tabular}

\section{Conclusion:-}

We have observed various presenting features for pleural effusion are short ness of breath, cough, fever, chest pain etc.; sand important disease factors for the occurrence of pleural effusion such as tubercular effusion, par pneumonic effusion, malignant effusion, congestive heart failure etc. This study would help in early diagnosis and prompt treatment of patients with pleural effusion especially in remote areas which remains a challenging problem. More detailed epidemiologic studies are required to improve understanding of the burden of pleural effusion with its potential risk factors in this region.

\section{Financial support and sponsorship -}

Nil.

\section{Conflicts of interest -}

There are no conflicts of interest 


\section{References:-}

1. Light RW. Clinical practice. Pleural effusion. 1. New England Journal of Medicine, 2002, 346: 1971-1977.

2. Marel $\mathrm{M}$ et al. The incidence of pleural effusion in a well-de2. Fined region. Epidemiologic study in central Bohemia. Chest, 1993, 104: 1486-1489.

3. Afful B et al. The characteristics and causes of pleural effusions 3. in Kumasi Ghana-a prospective study. Tropical Doctor, 2008, 38: 219-220.

4. Koffi $\mathrm{N}$ et al. Etiologies of pleurisies in African milieu. Experi4. ence of the Cocody Pneumology department. Revue de Pneumologie Clinique, 1997, 53: 193-196.

5. Miserocchi G (1997) Physiology and pathophysiology of pleural fluid turnover. Eur Respir J, 10: 219-25.

6. Light RW. Pleural Diseases Third Edition. Baltimore, MD: Williams and Wilkins; 1995. [PubMed]

7. Chetty KG. Transudative pleural effusions. Clin Chest Med. 1985; 6: 49-54.

8. Light RW. Diagnostic principles in pleural disease. Eur Respir J. 1997; 10: 476-81.

9. Storey DD, Dines DE, Coles DT. Pleural effusion: a diagnostic dilemma. Journal of the American Medical Association. 1976; 236: 2183-6.

10. Keshmiri M, Hashemzadeh M. Use of cholesterol in differentiating of exudative and transudative pleural effusions. Medical journal of the Islamic Republic of Iran. 1997; 2(3): 187-9.

11. Davies CW, Gleeson FV, Davies RJ (2003) BTS guidelines for the management of pleural infection. Thorax, 58 (Suppl 2): ii18-28

12. Antunes G, Neville E, Duffy J, Ali N (2003) BTS guidelines for the management of malignant pleural effusions. Thorax, 58 (Suppl 2): ii29-38.

13. Peto J, Hodgson JT, Matthews FE, Jones JR (1995) Continuing increase in mesothelioma mortality in Britain. Lancet, 345: 535-9.

14. Valdes L, Pose A, San Jose E, Martinez Vazquez JM (2003) Tuberculous pleural effusions. Eur J Intern Med, 14: 77-88.

15. Berger HW, Mejia E (1973) Tuberculous pleurisy. Chest, 63: 88-92.

16. Epstein DM, Kline LR, Albelda SM, Miller WT (1987) Tuberculous pleural effusions. Chest, 91: 106-9.

17. Kalaajieh WK. Etiology of exudative pleural effusion in adults in north Lebanon. Canadian respiratory journal. 2001; 8(2): 93-7.

18. Liam CK, Lim KH, Wong CM. Causes of pleural exudates in a region with a high incidence of tuberculosis. Respirology. 2000; 5: 33-8.

19. Light RW, Erozan YS, Ball WC Jr. Cells in pleural fluid: their value in differential diagnosis. Arch Intern Med. 1973; 132: 854-60.

20. Yam LT. Diagnostic signifi cance of lymphocytes in pleural effusions. Ann Intern Med. 1967; 66: $972-82$. 